\title{
Accountability and Blame Avoidance After Crises
}

Sanneke Kuipers and Annika Brändström

\section{ABSTRACT}

The post-crisis accountability process is a purification ritual that serves to channel public emotions and enables re-equilibration after a severe disturbance of the sociopolitical order. Crisis accountability literature can be reviewed in terms of forums, actors, and consequences. This setup allows a systematic discussion of how crises impact: the accountability process in influencing its setting (the forum); the strategies of accountees and their opponents (actors); and the resulting outcomes in terms of reputation damage, sanctions, and restoration (consequences). There is a clear distinction between formal and informal accountability forums, with the media being almost exclusively informal, and judicial forums, accident investigators, and political inquiries having formal authority over accountability assessments. Yet, through the presence of formal authorities in media reporting, and because media frames influence the work of formal authorities, the different forums intensively interact in accountability processes. Looking at accountability strategies reveals that the number of actors involved in blame games is likely rising because of increasingly networked crisis responses, and the role of actors has become more important and personal in the crisis aftermath and accountability process. The consequences and success of individual actors in influencing the accountability outcomes is shaped by both institutional settings and individual skills and strategies. A current political power position that exceeds prior mistakes is an effective shield, and denial is the least effective though most commonly used strategy. Accountability processes remain a balancing act between rebuttal and repair. Yet after major crisis, renewal is possible, and post-crisis accountability can play a crucial role therein.

Keywords

crisis, accountability, blame, inquiry, scandal, reputation, image, legitimacy, resignation

Kuipers, S., \& Brändström, A. (Forthcoming). Accountability and Blame Avoidance After Crises. In Oxford Encyclopedia of Crisis Analysis. Oxford University Press.

doi:10.1093/acrefore/9780190228637.013.1498. 
Crises are commonplace in our societies, and regardless of their origin, they do more than threaten lives, critical infrastructures, and public or private properties. They also negatively impact citizens' feelings on safety and protection that legitimated the preexisting political institutional order (Boin, ' $t$ Hart, Stern, \& Sundelius, 2005; Kuipers \& 't Hart, 2014). Crisis management pertains to saving lives and restoring order at the scene of the incident but is also an activity that takes place within the top administrative and political structures. Events negatively affecting core functions in society are nearly all deemed unacceptable by key stakeholders, the media, and the public at large. As a consequence, crises trigger intense accountability processes, either focusing on the evaluation of performance at all levels of government in anticipating or responding to the crisis, or questioning shortcomings of the underlying institutional order.

The post-crisis accountability process is a purification ritual that serves to channel public emotions and enables re-equilibration after a severe disturbance of the sociopolitical order. Crises reveal a "collapse of precautions that had hitherto been regarded culturally as adequate" (Turner, 1976, p. 380). Crises expose structural inadequacies that not only need repair but also require some form of retribution. Purification ritual may sound benign, but the blame games that ensue in the process may not always do justice to those involved, nor does it always facilitate a truth-finding dialogue or learning process in the wake of a crisis.

Various accountability narratives compete for attention, and their advocates engage in escalating debates so that their version becomes dominant in public and political perception of the truth. Crisisinduced accountability debates center on three key questions: (a) the origins of the crisis: How could this have happened in the first place?; (b) the response to the crisis: Was it appropriate and sufficient?; and (c) the lessons that can be drawn from this event: What political and policy implications should it have? (Brändström, 2016). The competing answers to those questions often imply responsibility and blame.

The stakes are high for those slated with responsibility. Their power, reputation and careers, and/or the continuity of their organizations are at stake. The negativity bias among stakeholders (blame for potential losses outweighs credit for gains) instructs executives in political and organizational life to blame others and avoid blame themselves (Weaver, 1986).

The potential for negativity bias is especially acute in crises, since constituents are generally worse off than when the crisis begins, so that the reference point for citizens is the degree of loss suffered. All of these factors make crises an ideal setting to study blame. ... (Moynihan, 2012, p. 573, cf. Maestas, Atkeson, Croom, \& Bryant, 2008)

The article's review of the literature on crises and accountability draws heavily on blame avoidance research. After all, "public systems of accountability are centered on the desire to blame" (Maestas et al., 2008; Moynihan, 2012, p. 569; Romzek \& Ingraham, 2000). Blame avoidance studies, departing from Kent Weaver's seminal work in 1986, abound in comparative welfare state research, on the one hand (focusing on ex ante arrangements to avoid blame for unpopular policy decisions, cf. GreenPedersen, 2002; Pierson, 1994; Vis, 2016), and on public policy and administration research, on the other (Hinterleitner, 2017). The latter branch of research includes many studies pertaining to a range, from human-made political crises and policy failures to natural and industrial disasters (e.g., Boin, 't Hart, \& McConnell, 2009; Brändström \& Kuipers, 2003; Hinterleitner \& Sager, 2015; Hood, 2002; Hood et al., 2009).

This article provides an overview of the academic discussions on accountability and blame management in response to crises. There is a vast literature on accountability and blaming, but this article zooms in on crisis situations in particular, which both limits and broadens the scope. The focus 
here is on crises that fit the classic definition as highly negative and disruptive events or episodes characterized by threat, urgency, and uncertainty (Rosenthal Charles, \& 't Hart, 1989). This focus makes the scope more limited than generic accountability studies in the sense that it excludes discussing accountability for routine government and policy performance. It includes insights from the public relations literature on private sector crisis accountability and therefore is broader than many of the above-cited public sector accountability approaches.

This article reviews the crisis accountability literature in terms of forums, actors, and consequences (in line with previous work-see Kuipers \& 't Hart's [2014] conceptualization based on Bovens, 2010). This setup allows a systematic discussion of how crises impact the accountability process in influencing its setting (the forum); the strategies of accountees and their opponents (actors); and the resulting outcomes in terms of reputation damage, sanctions, and restoration (consequences). When does accounting turn into accusing, and to what end? What are the key dynamics of blame games in the wake of crises, as a result of the interplay between forums, actors, and outcomes?

Institutional Impact: Forums

Similar to the way emergency services rush to the site of an accident, organizational watchdogs and investigative forums are spurred into action when incidents have occurred that warrant accountability. Forums can be divided into four categories according to their sphere of influence or authority: (a) media, (b) investigators, (c) judicial authorities, and (d) political inquiries (Kuipers \& ' $t$ Hart, 2014; cf. McConnell, 2010). Here a distinction is made between formal and informal accountability forums, with the media being an almost exclusively informal forum and the other three categories having formal authority over accountability assessments. What can be seen is that, through the presence of formal authorities in media reporting, and because media frames influence the work of formal authorities, the different forums interact in accountability processes.

Media

Informal, or non-governmental, forums would typically include both traditional and social media but also non-government organizations (NGOs), citizen journalism collectives (think of the Bellingcat collective, Global Voices, or the Independent Media Center), and publication outlets of independent authors, journalists, and academic scholars. Many studies on blaming strategies in the more formal political arena show how media influence interactions between political opponents (Brändström, Kuipers, \& Daléus, 2008; Hinterleitner \& Sager, 2015; Hood et al., 2009; Hood, Jennings, \& Copeland, 2016; Resodihardjo, Carroll, Van Eijk, \& Maris, 2016; Stark, 2011). A rare study on blame avoidance in a nondemocratic regime (China) shows how authorities there face a pronounced trade-off between media transparency and secrecy in crisis management, with strong implications for formal accountability (Baekkeskov \& Rubin, 2016.

Media not only play a direct role as a forum that holds "the powers that be" accountable, but they also provide an informal venue for framing and blaming by formal actors. Particularly as an informal venue, the influence of social media has expanded considerably in the past decade. The use of social media platforms in attempt to impact political processes has profoundly influenced elections in Europe and the United States. Some social media enjoy more direct attention by formal actors (such as U.S. president Trump) than their traditional counterparts, for political and blame management purposes. Social media incorporate a wider range of users, including citizens beyond the reach of newspapers and national television, such as teenagers but also potential voters (Wukich, 2019). Social media platforms have become useful tools for actors seeking to construct or spread fake or misrepresented news with the aim of influencing a specific issue or process, sometimes with political purposes. Social media can be exploited as an effective machinery with increasing speed and 
targeted direction. For decision-makers, social media create a new arena in which they may have to defend or shape perceptions around a certain issue.

However, the rules of engagement in this forum seem to be different from politics as it has been known. It is not necessarily beneficial to get engaged at all because interactions give rise to even more attention to the issue and may be exploited. This is very different from other arenas where politics and blame are managed, where active engagement is usually a recommended strategy over silence. The specific role of social media actors in crisis research in general, but particularly on influencing blame games and accountability for crisis, is under-researched, but its importance is likely to increase to those involved (Kuipers \& Welsh, 2017).

Kuipers and ' $\mathrm{t}$ Hart identify four reasons why accusations and blame games escalate through mass media. First, blame games are more likely if a credible account of the causes of a crisis or the crisis response is lacking, or if something "fishy" emerged in public reporting and interpretation (Kuipers \& 't Hart, 2014, p. 591). It could be that incriminating information was not fully disclosed initially; alternative truths were exposed as being downright untrue; smoking guns were discovered; or hidden agendas and questionable motives revealed. Second, the lack of a bigger story may contribute to increased or continued media scrutiny. When there is nothing today to make the crisis yesterday's news, media benefit from digging further in the case at hand. Third, related, it is perfectly rational and commercially rewarding for media to use their limited resources on expanding and deepening their reporting on a particular crisis and its more endemic causes and consequences. Fourth and finally, visibility of the crisis and its victims, or on-the-ground manifestations of a failed response and its results, adds fuel to the media fire. These four conditions (fishiness, lack of other news, rational search behavior by media, and visibility of failure) allow for zooming in on actors and failures, bring previously unearthed aspects in focus, and feed and prolong the accountability process.

Professional reporters, NGO activists, and private citizens play a role in accountability and blaming through mass media as well. Of course, NGOs, particularly those who serve as critical watchdogs on human rights, have always been investigating the activities of authorities, side by side with journalism. In doing so, they collected and analyzed eye-witness accounts, physical proof, and incriminating documentation to find out what happened and to attribute responsibility. They long served as informal accountability forums. Some activists even create media hoaxes, such as the activists called the Yes Men, impersonating a company official stating that Dow Chemicals would finally take responsibility to compensate victims of the Bhopal disaster at the 20th anniversary of the disaster. The hoax was broadcasted by BBC news at prime time, causing a temporary wipe of $\$ 20$ billion off Dow's share value, before the "Dow spokesman" was unmasked as a fraudster (Graff, 2004, pp. 12-13). And ever since, these activists have more new technologies at their disposal.

Digitalization of files allows individual activists (think of Julian Assange and Wikileaks, Edward Snowden and the NSA) to expose government top secrets. Publicly accessible satellite imagery is being examined in detail by Internet sleuths on a mission to reveal what governments are doing on the ground (Clem, 2016). Sometimes their work even threatens to interfere with other, more formal accountability forums such as the joint investigation team working on the prosecution of those responsible for the crash of flight $\mathrm{MH}-17$ near Donetsk, Ukraine. When the Bellingcat collective publicly "compiled a very convincing case [which] revealed evidence about who shot the plane and how" (Clem, 2016), it also complicated the work of prosecutors and judges who could not allow external journalistic accounts to color their judgment. 
In July 2018, cooperation between a Dutch online news magazine and the Bellingcat collective revealed that defense ministry staff used a fitness app on their smartphones that leaked the names, addresses, and whereabouts of soldiers and secret agents (Martijn, Tokmetzis, Bol, \& Postmas, 2018). Along with revealing their findings publicly, they held the Dutch government to account for its omissions in protecting their staff. Satellite imagery and new technologies for data mining form a powerful combination with globally networked wikisites and social media, and the ubiquity of smart digital telecom devices. As such, these ICT advancements "shift power to the newly informed" (Florini \& Dehqanzada, 1999, p. 46). In response, Florini and Dehqanzada (1999, p. 52) argue that for authorities "the only practical choice is to embrace emerging transparency, take advantage of its positive effects and learn to manage its negative consequences." And authorities better do so because "little brothers" are watching them with increasing resources in their hands (Clem, 2016).

\section{Accident Investigators}

Accidents are not always crises for the larger society where they occur. That is, the consequences are sometimes limited to those directly affected, and the incident does not politicize or take on "focusing event" qualities (Birkland, 2007 Brändström \& Kuipers 2003). Catastrophic incidents such as the Herald of Free Enterprise (1987), Estonia (1994), and Costa Concordia (2012) shipping disasters; or tragedies in aviation such as the Tenerife disaster (1977), the Ueberlingen mid-air collision (2002), the Germanwings crash (2015), or the downing of flight MH-17 in Ukraine (2014) have become markers in the history of their transportation sector. Such accidents can expose structural deficiencies or spark off a debate on what we define as acceptable risks. In such cases, accident investigators and their conclusions suddenly have an inadvertent role in a politicized debate.

Formal accident investigations by regulatory bodies, inspectorates, and accident investigation boards are traditionally the authorities to analyze the causes of accidents, incidents (including near misses), and disasters. The investigators differ in terms of scope and mandate, and their presence and jurisdiction also vary between countries and functional domains. They provide an account of causes with the objective of learning from failure and improving operations and safeguards to increase safety in the future. They face the following challenges: (a) non-exclusivity, (b) impact from other accountability processes, (c) proliferation of competing accounts, and (d) the continuous tension between learning and accusing.

First of all, their search domain is not exclusive: investigators sometimes compete to provide their specific account of (aspects of) the same situation. They may even literally get in one another's way on the accident site, as was the case with different investigative bodies in the aftermath of the crash of Turkish airlines flight TK1951 (IOOV report, 2009, p. 56). Occupational health and safety inspectorates stand side by side with safety boards and other transportation accident investigators, manufacturers (e.g., Boeing or Airbus), environmental protection agencies, chemical or nuclear safety agencies, and many more, to investigate, for instance, a single crash site.

Second, their work is affected by the verdicts of others. Even if they coordinate their investigations in order not to hinder one another, their findings and conclusions will likely affect the reports and findings of others. Third, their number seems to be on the rise for single incidents. In response to external investigations, responsible authorities under investigation often commission an internal investigation on top of it all. The Dutch Safety Board (DSB) explicitly recognized this trend in its 2018 publication on independent investigations (DSB, 2018). The increase in accountability arrangements and the growing complexity thereof comes at a cost: "Almost by definition, multiple accountability is seen as too much of a good thing, as a burdensome overload" (Schillemans \& Bovens, 2011, p. 1). 
The fourth and final challenge discussed here is perhaps most important with respect to blaming: each investigation, even if purely focused on learning and improvement, makes those responsible for whatever has contributed to the incident at hand stand accused. Catino (2008) concludes from his literature review that "though favored by scientists, the organizational function approach [focused on learning from accident investigations] is in real life often beaten by the individual blame logic [the accusatory approach to accident investigation]" (Catino, 2008, p. 53). Elliott and McGuinness (2002, p. 20) agree in their article on accident investigations' propensity to (indirectly) blame individuals and agencies, even if the purpose of the investigators is to draw lessons and prevent future crises. After all, "any identification of human error will at the very least encourage the pursuit of subsequent litigation."

\section{Judicial Forums}

Though formally separate processes, it is unlikely that judicial authorities, prosecutors, or coroners will ignore the outcomes of accident investigations. Their primary aim is, however, not just to establish causality, but in fact to ascertain responsibility and culpability. Kuipers and 't Hart (2014, p. 592) call this the "forensic paradigm of accountability." Similar to accounts by media and professional investigators, judicial forums and their findings can break careers of those involved at all levels in the accident or its causes. What characterizes judicial processes is their high cost in terms of money and time. Crises cast a long legal shadow, and the costs are extreme.

Although professional accident investigation processes are usually completed within one or two years after an incident, and political inquiries may take even longer, judicial trials trump them all (see Brändström \& Kuipers, 2003; Elliott \& McGuinness, 2002, p. 19). The settlement of the 1984 Union Carbide toxic disaster in Bhopal took more than 20 years in the Indian and U.S. courts. The trials of the 1989 Hillsborough Football Stadium disaster are still running in the U.K. courts 30 years after the incident (BBC, 2018). The BP oil spill was finally settled for $\$ 20$ billion by the U.S. Federal Court in 2016, six years after the incident in 2010. "This might not be the end of legal troubles for BP, however. The company is facing yet another lawsuit related to the spill-in Mexico" ("BP Oil Spill," 2016). Also, public health investigations on the effects of the clean-up on local workers' health are still ongoing and may lead to new judicial charges (Konkel, 2018). Unfortunately, unlike companies and governments, individual victims do not always have the time and resources to see the blame materialize in judicial trials. For instance, many Hillsborough witnesses and victims' relatives died during the trial process (Conn, 2018).

\section{Political Inquiries}

A typical response to unfortunate events, scandals, or policy failures is to launch an inquiry by a blueribbon committee, royal commission, or other independent inquisitor (Boin et al., 2009). Elliott and McGuinness (2002, p. 14) to assess the usefulness of "an instrument born of the late 19th century" (the public inquiry) for evaluating contemporary crisis management by criticizing the (a) impartiality, (b) scope and process, and (c) the underlying purposes of political inquiries. Most of their criticism on implications for learning, in fact, holds equal implications for blame management.

Impartiality: Elliot and McGuiness (2002) point out that governments usually seek to distance themselves from the inquiry by appointing independent investigators. Political incumbents need to avoid the impression of setting up an inquiry committee just to clean their slate, so they select committee members of impeccable reputation and in possession of nonpartisan credentials (Kuipers \& 't Hart, 2014, p. 592). In a comparative study of 15 crisis cases, Boin et al. found that incumbent politicians did what they could to "prevent the inquiry from being run in the adversarial, politicized legislative arena," resulting in the majority of inquiries being commissioned to blue-ribbon 
committees or senior lawyers (Boin et al., 2009, p. 98). Though such committees were still highly critical of their own government, their expert-driven inquiries tended to focus on "regulatory, managerial and cultural factors" and they were less likely to result in political fatalities (Boin et al., 2009, p. 98).

However, true impartiality of inquiries, even by so-called independent investigators, is not selfevident. Elliott and McGuiness (2002) criticize the unrepresentative selection of committee members (they may in fact only represent the elite because of their credentials and reputation) and emphasize that not only their elite status but also their disciplinary background (judges, in the United Kingdom) may influence their inquiry. Even if impartiality of an inquiry committee could be established, it seems to no avail for blame avoidance purposes. An empirical study by Sulitzeanu-Kenan (2006) shows how independent inquiries not only fail to reduce blame attribution in general, but they are also considered no more credible than partisan inquiries unless their conclusions are very negative of incumbent actors.

Scope and process: When commissioning an inquiry, authorities also influence the scope from the outset. Historical evidence shows that if, for instance, concerns about hooliganism are dominating the political agenda, an inquiry into a football stadium disaster may be very much cast in that light, not only distracting from underlying problems such as crowd control but also attributing responsibility at a particular level (the hooligans, not the custodians) (see Elliott \& McGuiness 2002; Elliott \& Smith, 1993). The scope may not only be set and biased from a specific perspective, but it may also be too narrow-focusing on immediate, technical causes - to take into account the more structural, endemic policies that contributed to failure (Hutter, 1992, cf. Brändström \& Kuipers, 2003). The inquiry process takes time, which makes sense in terms of quality and thoroughness but also can impede political accountability. When years pass between the incident, the commissioning of an inquiry, and the presentation of its conclusions, the responsible actors may be long gone from the political scene, leaving it to the new political incumbents to account for their predecessors. Sulitzeanu-Kenan (2007, p. 642) shows that political executives do not per se need to establish inquiries to buy time when they find themselves subject of criticism and blame. Media salience also subsides after an attention peak of three weeks for similar issues that are not followed up with an inquiry (Sulitzeanu-Kenan, 2007).

Underlying purposes: Although inquiries often formally solely focus on learning and truth finding, their identification of failure will most likely influence blame attribution. This may not be their purpose, but it is such a persistent and ubiquitous side effect that it cannot be ignored. In terms of blame avoidance, as Sulitzeanu-Kenan (2010, p. 631) shows, inquiries are fundamentally negative goods for political executives. Their impartiality is by definition contested (Elliott \& McGuiness 2002; Sulitzeanu-Kenan, 2006); the time bought by kicking the ball in the long grass is inconsequential for escalation of the blame game (Sulitzeanu-Kenan, 2007); and their conclusions will likely increase the attribution of blame (Sulitzeanu-Kenan, 2010). Incumbents will need to consider other blame management strategies. The next section, "Actors and Their Strategies" therefore discusses research findings on actors and their strategic responses or orientations to blame.

\section{Actors and Their Strategies}

The increased mediatized visibility of crises and leaders, combined with the drive for more transparency, learning, and inquiry, have made the role of actors during crises and their aftermath more important and personal. In addition, trans-boundary crises imply that multiple agency involvement in crisis causes or responses, and hence the number of actors and organizations in 
blame games, is on the increase. Different disciplines in crisis research reveal a trend toward more attention for actors and their strategies, and meanwhile bring a variety of insights to the table.

Crisis research from an international relations or more generic political science perspective has always had a focus on leaders and their responsibilities. Foreign policy crises such as the Cuban missile crisis, the Bay of Pigs invasion, and the intrusion of a Russian submarine into Swedish territorial waters pointed at the key roles of leaders and their administrations (Brändström, 2016). As a result, actors and blame attribution were a natural topic of interest when foreign policy failures became apparent (Bovens \& 't Hart, 1998; Ellis, 1994; Kuipers et al., 2011; Walsh, 2006). Political science studies originally focusing on democratic accountability more generally showed how crises are pivotal in shaping and bringing to life formal and informal institutional rules and norms (Stark, 2011).

Crisis studies originating from disaster sociology and public administration came to conclude that crises cast long shadows. Crises profoundly affect legitimacy, trust, and risk perception, which brought in meaning-making and accountability as critical leadership tasks (Boin et al., 2005).

In judging the success or otherwise of crisis management initiatives it is tempting to focus on individuals ... especially because they 'humanise' the crisis management process, often attracting media attention for the better (President Piñera and the rescue of the Chilean miners) or worse (FEMA chief Michael Brown and hurricane Katrina). (McConnell, 2011, p. 65)

Crises need a face, and political executives provide those. Most studies acknowledge that crisis managers encounter a "mission impossible" and that fair judgments are scarce (Boin, Kuipers, \& Overdijk, 2013; Boin \& 't Hart, 2003; McConnell, 2011). Yet, the incentives and occasions for blaming (other) actors, and the challenges to actors in terms of blame avoidance, abound.

Studies combining crisis research with a focus on policy networks and political delegation point out that not only individual actors face blame in crisis. Moynihan (2012) made an important contribution to the literature by describing the increasing importance of crisis response networks as subjects of blame and venues for blame avoidance. Agencies at arm's length of ministerial departments seem to be apt designs for blame avoidance by separating policy implementation from direct political responsibility (Hood, 2002). Hood (2011) even refers to such designs as the "agency strategy" for blame avoidance.

The chance of success of delegating blame away from the principal, or diffusing blame in a network, is subject to debate. Empirical studies of high-profile policy failures showed that even at arms' length, agents turn on their political principals when things go wrong (Hood \& Lodge, 2006). Moynihan (2012) even argues that independent agencies in crisis are more likely to blame their remote principals than previously, when they were integral parts of cabinet departments. Agencies and public managers with more attenuated relationships to the political principal have more incentives to avoid blame, and pass the buck upward in the delegation chain. Although their own organizational reputation is immediately at stake, their loyalty to remote partners or superiors in their network is not so strong. In addition, agencification and network governance increase the number of actors involved in a crisis response, and hence the number of potential participants in the blame game goes up, which may add fuel to the fire (Moynihan, 2012). Similar arguments have been made about multilevel governance responses and blame avoidance in geographically decentralized systems (Maestas et al., 2008; Mortensen, 2013).

In sum, the role of actors can be seen as becoming more important and more personal, and their number in blame games is on the increase. It can also be concluded that most studies treat 
motivations for actors in blame games as a given -in line with Weaver's (1986). Central to empirical research on actors in blame games and accountability processes hitherto were the strategies these actors employ. "Strategies: Dimensions and Stages" looks into those tactics and the mechanisms of escalation that make some accountability processes develop into highly politicized blame games, and others not.

\section{Strategies: Dimensions and Stages}

To avoid risk and blame, actors can choose between different basic strategies, including presentational, agency, and policy strategies (Hood, 2002). The latter two are anticipatory strategies that actors design into their system of responsibility (limiting formal responsibility for policy substance, the policy strategy) and accountability (shifting responsibility for policy implementation to others, the agency strategy) (Hinterleitner, 2017). The presentational strategy is a post-hoc and rhetorical one. When an event has already occurred, actors can no longer "organize" themselves out of trouble by means of limiting discretion or advocating delegation, they need to rely on denial or framing. Opponents, in turn, will position themselves to allocate blame toward incumbent actors and coalitions.

The governance literature on blame focuses on two distinct presentational strategies: blame avoidance and blame management (McGraw, 1991). Blame avoidance studies emphasize denial. The argument here is that political actors are most likely to initially attempt to deny responsibility for the unfortunate event, problematic response, or policy failure. Hood et al. (2009) coined the term "staged retreat," a strategy that entails consecutive steps starting with denial of the problem; then resorting to denial of responsibility for it; and only if all else fails, admitting both problem and responsibility (see also Hood, 2011; Resodihardjo et al., 2016; Resodihardjo, van Eijk, \& Carroll, 2012; Sulitzeanu-Kenan \& Hood, 2005).

Blame management strategies are characterized by framing. To frame is "to select some aspects of a perceived reality and make them more salient in a communicating text in such a way as to provide a particular problem definition, causal interpretation, moral evaluation and/or treatment recommendation ..." (Entman, 1993, p. 52). Framing occurs along several dimensions: severity (Why is this so bad?), agency (Is this a structural policy problem or an operational incident?) and responsibility (At what level and on whose watch did it occur?) (Brändström \& Kuipers, 2003). Media are experts in framing, but so are politicians and agency administrators of all stripes and colors.

The blame game involves not only those who defend themselves but also active predators, particularly but not exclusively so in majoritarian political systems (Boin et al., 2009; Brändström, 2016; De Ruiter, 2017; Hinterleitner, 2017, p. 222). Negative events are not blameworthy by definition, but they are often made blameworthy by political opponents framing the issue as such. Their motivations can vary, from preemptively striking in order to avoid blame on their own turf, to deliberately weakening the reputation of opponents or politicizing a policy practice in order to centralize authority. Hinterleitner (2018) provides a compelling account of the latter in his analysis of a politicized case of the implementation of a Swiss juvenile justice policy. Other case studies reveal the deliberate mutual attacks between political parties, levels, and branches of government, such as after hurricane Katrina (Boin et al., 2010; Moynihan, 2012), the Iraq Wheat scandal (McConnell, Gauja, \& Botterill, 2008), the Boxing day tsunami (Brändström et al., 2008), the Australian home insulation policy fiasco (Hinterleitner \& Sager, 2015), and the Abu Ghraib scandal (Kuipers et al., 2011).

Though accountability processes can suffer from "the problem of many hands" when responsibility is diluted (Thompson, 1967, the above cases point at patterns and mechanisms of escalation. The more 
actors involved in both blaming and receiving blame, and the more domains of responsibility are implicated, the more fuel on the blame game and the politicization of the situation at hand (Brändström et al., 2008). What further fuels escalation are the characteristics of the issue and the particular setting in which a crisis occurs (such as election time, or the composition of government coalitions or composition of collaborative networks) (Boin et al., 2009).

The public governance and crisis management literature has learned much from the business administration domain on how crisis characteristics and context affect blame attribution. Public affairs scholars have long investigated how pre-crisis reputation, crisis history, and organizational reputation affect the attribution of responsibility for the next event (Coombs, 2007). Hearit (2006) and Benoit (1995) point out that aspects such as visibility (of the damage or suffering), excusability (values violated, perceived intentionality), and identification with victims, make some crises worse than others as amplifiers of blame. The public affairs literature has contributed much on crisis mitigation and damage control because of its focus on the consequences of crises in terms of blame attribution. The next section, "Consequences," discusses how accountability of public actors and their organizations for crises translates into consequences.

\section{Consequences}

\section{Sanctions and Resignations}

The outcomes of blame games can generate a wide range of consequences to individual organizations or officeholders; scapegoating lower-level operators, singling out failed policymaking or policymakers, or revealing fundamentally flawed systems of policymaking and operations. Studies of blame management have also demonstrated that responsibility and blame seem to move up the ladder of hierarchy once put in motion. Hence the stakes for top office holders are particularly high (Boin et al., 2009; Brändström, 2016).

The success for individual actors in influencing the outcome of such blame games are shaped by institutional settings (e.g., the parliamentary system) as well as their individual skills in managing and positioning themselves with regard to accountability (De Ruiter, 2019). Both the institutional and the individual perspectives are crucial in understanding the sanctions that may follow on blame games (Brändström, 2016). According to Moynihan (2012, p. 569), Maestas et al. (2008), and others, our public accountability systems are increasingly focused on assigning blame. Hence, demands for resignations as a remedy also seem to increase (Hinterleitner \& Sager, 2019 p. 134; Weaver, 2018). When the Swedish transportation agency had outsourced digital data platforms that were accessible to a foreign company without what appeared to be the proper security clearance, the head of the agency was forced to resign. The critique against the government continued and subsequently led to the resignation of two cabinet ministers ("Transportstyrelsens it-affär," 2017).

The tenure of political leaders in general has long been of interest to public policy studies (Hansen, Klemmensen, Hobolt, \& Bäck, 2013; Mesquita, Smith, Siverson, \& Morrow, 2005). Their findings also provide important perspectives regarding the more specific relationship between crisis accountability and resignations of politically appointed leaders. In Western parliamentary democracies, the accountability relationship stems from the chain of delegation linking the electorate to individual political executives through parliament (Ström, 2003). Accountability and sanctions follow this delegation, and the government is ultimately evaluated through elections. In this perspective, how long a political actor manages to stay in office is ultimately determined by those parties who have decided to form the coalition government (Mesquita et al., 2005). However, Mesquita et al. (2005) also conclude that the situational and political context are equally important for the tenure of 
political leaders. Crises are important markers with respect to the situational context in which we assess the performance of political executives.

The reasons why political leaders resign in general vary. Woodhouse (2004) and Dowding and Lewis (2012) suggest that failure to perform in one's role (in relation to parliament) and natural causes (age, illness) are primary causes for resignation. Ministerial drift-moving too far away from the agreed-on party or policy line-may be another cause for resignation (Indridason \& Kam, 2008). Ministers can also be "called" or forced to resign because of a breach of trust with the prime minister, personal scandals, or a mismanaged crisis (Bäck, Meier, Persson, \& Fischer, 2012; Bovens, 2010; Dowding \& Lewis, 2012). The consequences of crisis can follow near instantaneously or years down the road. For instance, Spain's Prime Minister Aznar was voted out of office three days after the Madrid bombings in 2004 when he was accused of misleading the public about the cause of the attacks (Canel, 2012). The entire Dutch cabinet stepped down years after a crisis (in 2002) when an inquiry committee concluded that the Dutch government had to take responsibility for the failed UN protection of Bosnian Muslims in Srebrenica in 1995 (Brändström \& Kuipers, 2003).

The setting in which a crisis occurs has a profound impact on political sanctions. Most scholars agree that cases of resignation often correlate with intense and negative media scrutiny (Boin et al., 2005; Dowding \& Lewis, 2012; Woodhouse, 2004). When precisely a crisis hits in the electoral cycle also affects the likelihood and the intensity of blame games (Boin, McConnell, \& ' $t$ Hart, 2008). Individual characteristics such as personal and professional backgrounds, age, gender, political capital, and prior experiences of the actors involved greatly influence how well they cope with pressures to resign (Berlinski, Dewan, \& Dowding, 2007; Daléus, 2012).

Studies in the Netherlands, Sweden, and Germany indicate that political experience (in parliament or cabinet) is a factor that protects ministers from having to leave office (see Bäck, Persson, \& Meier, 2009; De Ruiter, 2019; Fischer \& Kaiser, 2009). Leaders with a better understanding of the rules and procedures of the political arena are simply better at exploiting them to their advantage. The relative importance of a minister to the prime minister and his or her power position in the party and/or cabinet also seem important as protection from resignations (Dowding \& McLeay, 2011). Factors such as leadership capital and pre-crisis credibility are important factors also for the tenure of political leaders (Bennister, 't Hart, \& Worthy, 2015). Research on Swedish post-crisis resignations support the notion that a political power position and relative importance to the prime minister exceeds prior mistakes. In the Swedish cases, parliament could not independently enforce resignations of ministers. A necessary factor seemed to be decreasing public and cabinet support. Calls for resignations were usually initiated by the prime minister in order to secure the stability of cabinet and government (see Brändström, 2016).

The public inclination to assign responsibility for crises in combination with expectations of resignations will place individual actors at the heart of the blame game. Given the potential consequences, we can assume that actors tend to expand their toolbox to manage blame and sanctions in order to avoid the most unwanted consequences, including pressures to resign. In the next section, we discuss "Image Restoration" as a perhaps more positive outcome of crisis accountability.

Image Restoration

Though reputations can be partly repaired, once an accountable executive stands accused of mishandling a crisis, tolerance for future missteps is gone (De Ruiter, 2019). The one factor that seems to have a real shielding effect is a current political power position that exceeds prior mistakes (Brändström, 2016, p. 124). Though Berlinski, Dewan, and Dowding (2010) concluded from a 
longitudinal study that most calls for political sanctions do not in fact lead to direct resignation, the damage to the executive's reputation makes remaining in office difficult. Only $30 \%$ of the executives who faced one or more resignation calls ultimately complete their term (Berlinski et al., 2010, p. 563; Kuipers \& ' $t$ Hart, 2014). Subsequent performance will be scrutinized more intensely or less forgivingly, and in particular a next crisis is likely to nail the coffin (De Ruiter, 2019).

The public affairs literature is more optimistic. Self-disclosure of mishaps and failures help to reduce the attribution of blame (Arpan \& Roskos-Ewoldsen, 2005; Claeys \& Cauberghe, 2012). Apologies, corrective action, and mortification can help corporations and their executives to bounce back strongly. As long as their response to the reputational threat or accusation is commensurate to the scope and intensity of the threat, recovery and regaining of trust is possible (Benoit, 1995).

To respond appropriately to a reputational threat, the threat first needs to be assessed accurately. Coombs (2007) advises that such an assessment includes whether the current issue is related-in the perception of stakeholders-to any previous negative events (the crisis history of the accused). Also, the organization under fire should do some soul-searching on how it has been treating its stakeholders in the past (the distinctiveness of the wrongdoings). In combination with the alleged intentionality of the issue at hand, the pre-crisis reputation defines the severity of the blame attribution. High perception of intentionality combined with damaged pre-crisis reputation requires more efforts to compensate the damage, apologize, and reach out, than scandals that are "first offences" against the backdrop of an otherwise impeccable reputation (Coombs, 2007). Though this line of argument seems to state the obvious, many corporate actors - similar to politiciansmiscalculate or underestimate the reputation threat or blame they face and try to "get away" with initial denial or minimal compensatory efforts to the affected, making matters worse in the public eye.

A meta study by Arendt, LaFleche, and Limperopulos (2017) reveals that denial is the least effective strategy, yet the one most commonly used by organizations in response to threats and blame. Instead, corrective action-one of Benoit's famous strategies for image repair-is the most successful (Arendt et al., 2017; Benoit, 1995). Case studies of organizations that respond generously or even overcompensate show that accusations can be turned into opportunities, such as IKEA's response to the discovery of horsemeat in its famous meatballs in 2013 (Bik, Ngai, \& Falkheimer, 2017).

Though few would argue that there are important differences between the public sector and the corporate sphere, it is striking how students of political science and public administration seem to focus mostly on blame management, whereas business administration scholars in public relations focus more on image repair and apologia. So much so even, that leading corporate crisis communication scholars Ulmer and Sellnow (2002, p. 362) lamented that "crisis-related discourse is most often about an organization or industry absolving itself from guilt and repairing its image" using the apologia toolkit. These apologia can repair the reputation damage after product recalls and corporate scandals and are therefore instrumental to recover a brand's popularity as soon as possible. Yet such repair strategies do not per se improve the position of the organization more structurally. In crises with an external cause (such as terrorist attacks or natural disasters), Ulmer and Sellnow argue that opportunities arise to replace the discourse of apology with emphasis on rebuilding and renewal (2002). This argument is in line with studies on crisis management in the public sector that focus on crisis exploitation (Boin et al., 2009) and institutional renewal (Ansell, Boin, \& Kuipers, 2016).

Conclusion 
This article systematically discussed how crises impact the accountability process in terms of its setting (the forum); the strategies of blame avoidance by those involved (actors); and the effects of blame and blame avoidance or apology strategies in terms of reputation damage, sanctions, and restoration (consequences). In recapping this discussion, important avenues for future research can be found with regards to the role of the diversification and direct impact of social media on the crisis accountability process. As Stern (2017) puts it,

The rise of social media and personal communications technology ... has profound implications for the accountability process. The media, public sector accountability fora, and other actors in public discourse are now provided with real time information, competing accounts regarding incidents, and feedback (though not necessarily sound, systematic, or reliable) regarding citizen reactions and satisfaction with services provided by crisis actors. In other words, the scope, complexity, granularity, and accessibility of accountability-relevant information have increased dramatically. (Stern, 2017, p. 6)

Although the (social) media are themselves almost exclusively informal forums of accountability, they seem to have considerable impact on the work of accident investigators, judicial forums, and political inquiries having formal authority over accountability assessments. Not only do social media report and criticize on the work of these forums before the investigation is completed, they are also increasingly important channels of crowdsourced data and findings that may or may not positively contribute to the work of investigators, prosecutors, or inquiry committees. In addition, they are venues for disinformation, controversy, and ambiguity that compete for political and public attention at unprecedented levels. Future research on how social media play a role in influencing the work of different crisis accountability forums would be highly valuable.

Looking at accountability strategies reveals that the number of actors involved in blame games is likely rising because of increasingly networked crisis responses. Also, the role of actors has become more important and personal in the crisis aftermath and accountability process. Social media provide more information than ever before on responsible actors' actions and on their popularity. Political executives are easily being photographed and personally exposed in settings, places, and contexts that can be considered as inappropriate during the crisis response phase (the Dutch prime minister on a sunny terrace in shorts in the week after the downing of flight MH17, or Secretary of State Condoleeza Rice shopping at Manolo Blahnik's on the day after hurricane Katrina made landfall). Media appearances in individual or consecutive crisis situations form an easy and visible trail. Media provide immediate criticism and feedback on the popularity of actions by public leaders, which may be difficult to keep up with in terms of response or difficult to curb once a particular image or picture has gone viral. The impact of social media on the more personal nature of accountability processes could be another avenue for further study.

The consequences and success of individual actors in influencing the accountability outcomes is shaped by both institutional settings and individual skills and strategies. A current political power position that exceeds prior mistakes is an effective shield, and denial is the least effective, though most commonly used, strategy. If social media make accountability processes more personal and direct, the impact of institutional settings on the consequences and success of blame avoidance strategies is likely to change. If the accountability process becomes more person than role focused, and more direct, it may result in a convergence of strategies in the public and private sector, in different political settings, with more similar outcomes. There is much to learn between the different literatures from the fields of business administration and public affairs, on the one hand, and political science, public administration, and disaster studies, on the other, which could and should inform future research. 
Accountability in times of crisis is a balancing act between rebuttal and repair. It takes place in a diversity of forums: media, accident investigations, judicial investigations, and political inquiries. Each of these forums offers different challenges for politically responsible actors in crisis, in terms of accountability. The strategies at their disposal vary from denial to complete mortification. There is more optimism in the private sector than in the political realm regarding the effect of these strategies. Both public and business administration scholars cynically agree that blaming as well as quickly apologizing gets in the way of structural improvements. At the same time, they also agree that renewal is possible and that accountability after crisis can play a crucial role here.

\section{References}

Ansell, C., Boin, A., \& Kuipers, S. (2016). Institutional crisis and the policy agenda. In N. Zahariadis (Ed.), Handbook of public policy agenda-setting (pp. 415-432). Cheltenham, U.K.: Edward Elgar.

Arendt, C., LaFleche M., \& Limperopulos, M. (2017). A qualitative meta-analysis of apologia, image repair, and crisis communication: Implications for theory and practice, Public Relations Review, 43(3), 517-526.

Arpan, L. M., \& Roskos-Ewoldsen, D. R. (2005). Stealing thunder: Analysis of the effects of proactive disclosure of crisis information. Public Relations Review, 31, 425-433.

Bäck, H., Meier, H., Persson, T., \& Fischer, J. (2012). European integration and prime ministerial power: A differential impact on cabinet reshuffles in Germany and Sweden. German Politics, 21(2), 184-208.

Bäck, H., Persson, T., \& Meier, H. E. (2009). Party size and portfolio payoffs: The proportional allocation of ministerial posts in coalition governments. Journal of Legislative Studies, 15, 12-34.

Baekkeskov, E., \& Rubin, O. (2016). Information dilemmas and blame-avoidance strategies: from secrecy to lightning rods in Chinese health crises. Governance, 30(3), 425-443.

Bennister, Mark, 't Hart, P., \& Worthy, B. (2015). Assessing the authority of political office-holdersthe leadership capital index. West European Politics, 38(3), 417-440.

Benoit, W. L. (1995). Accounts, excuses and apologies: A theory of image restoration. Albany, NY: State University of New York Press.

Berlinski, S., Dewan, T., \& Dowding, K. (2007). The length of ministerial tenure in the UK, 1945-1997. British Journal of Political Science, 37(2), 245-262.

Berlinski, S., Dewan, T., \& Dowding, K. (2010). The impact of individual and collective performance on ministerial tenure. Journal of Politics, 72, 559-571.

Bik, S., Ngai, C., \& Falkheimer, J. (2017). How IKEA turned a crisis into an opportunity. Public Relations Review, 43, 246-248.

Birkland, T. (2007) Lessons of Disaster: Policy Change After Catastrophic Events, Washington DC: Georgetown University Press.

Boin, A., 't Hart, P., McConnell, A. and Preston, T. (2010) Leadership Style, Crisis Response and Blame Management: The Case of Hurricane Katrina, Public Administration, 88(3), pp. 706-723. 
Boin, A., Kuipers, S., \& Overdijk, W. (2013). Leadership in times of crisis: A framework for assessment. International Review of Public Administration, 18(1), 79-91.

Boin, A., McConnell, A., \& 't Hart, P. (2008). Governing after crises: The politics of investigation, accountability and learning. Cambridge, U.K.: Cambridge University Press.

Boin, A., \& 't Hart, P. (2003). Public leadership in times of crisis: Mission impossible? Public Administration Review, 63(6), 544-553.

Boin, A., 't Hart, P., \& McConnell, A. (2009). Crisis exploitation: Political and policy impacts of framing contests. Journal of European Public Policy, 16, 81-106.

Boin, A., 't Hart, P., Stern, E., \& Sundelius, B. (2005). The politics of crisis management: Public leadership under pressure. Cambridge, U.K.: Cambridge University Press.

Bovens, M. (2010). Two concepts of accountability: Accountability as a virtue and as a mechanism. West European Politics, 33(5), 946-967.

Bovens, M., \& 't Hart, P. (1998). Understanding policy fiascoes. New Brunswick, NJ: Transaction.

BP oil spill: Judge grants final approval for \$20bn settlement. (2016, April 4). The Guardian.

Brändström, A. (2016). Crisis, accountability and blame management-strategies and survival of political office holders. (Doctoral dissertation). Utrecht University, The Netherlands.

Brändström, A., \& Kuipers, S. (2003). From "normal incidents" to political crises: Understanding the selective politicization of policy failures. Government and Opposition, 38, p. 279-305.

Brändström, A., Kuipers, S., \& Daléus, P. (2008). The politics of blame management in Scandinavia after the tsunami disaster. In Boin et al. (Eds.), Governing after crises: The politics of investigation, accountability and learning (pp, 114-147). Cambridge, U.K.: Cambridge University Press.

Canel, M. J. (2012). Communicating strategically in the face of terrorism: The Spanish government's response to the 2004 Madrid bomb attacks. Public Relations Review, 38(2), 214-222.

Catino, M. (2008). A review of literature: Individual blame vs. organizational function logics in accident analysis. Journal of Contingencies and Crisis Management, 16(1), 53-62.

Claeys, A. S., \& Cauberghe, V. (2012). Crisis response and crisis timing strategies, two sides of the same coin. Public Relations Review, 38, 83-88.

Clem, R. S. (2016, February 23). Here's how to catch atrocities and human rights violations. The Washington Post.

Conn, David (2018) Hillsborough Officer in Charge Fails to Put a Stop to His Prosecution, The Guardian, December 6, 2018.See https://www.theguardian.com/football/2018/dec/06/hillsboroughofficer-in-charge-fails-to-put-a-stop-to-his-prosecution

Coombs, T. (2011). Ongoing crisis communication: Planning, managing and responding. Thousand Oaks, CA: SAGE.

Coombs, W. T. (2007). Protecting organization reputation during a crisis. Corporate Reputation Review, 10, 163-176. 
Daléus, P. (2012) Politisk ledarskapsstil: Om interaktionen mellan personlighet och institutioner I utövandet av det svenska statsministerämbetet. (Doctoral dissertation). Stockholm, Sweden: Stockholms Universitet.

De Ruiter, M. (2017). A common response to blame? Elite expectations of minister's blame management tactics in two political cultures. Paper presented at the European Group of Public Administration (EGPA) conference, Milan, Spain.

De Ruiter, M. (2019). Walking the tightrope: Political accountability, blame, and ministerial survival in two parliamentary systems. (Doctoral dissertation). Utrecht University, The Netherlands.

Dowding, K., \& Dumont, P. (2009). The selection of ministers in Europe: Hiring and firing. New York, NY: Routledge.

Dowding, K., \& Lewis, C. (2012). Ministerial careers and accountability in the Australian commonwealth government. Canberra: ANU E Press.

Dowding, K., \& McLeay, E. (2011). The firing line: When and why do prime ministers fire ministerial colleagues? In P. 't Hart \& J. Uhr (Eds.), How power changes hands: Transition and succession in government (pp. 157-173). London, U.K.: Palgrave Macmillan.

Dutch Safety Board (2018) Onafhankelijk Onderzoek in het Publiek Belang, March 2018, The Hague, Onderzoeksraad voor de Veiligheid. See also https://www.onderzoeksraad.nl/nl/media/inline/2018/7/10/74febf62b9dcovv_20183262_interactie ve_versie_strategische_leeropdracht_180306.pdf

Elliot, D., \& McGuinness, M. (2002). Public inquiry: Panacea or placebo? Journal of Contingencies and Crisis Management, 10, 14-25.

Elliott, D., \& Smith, D. (1993). Football stadia disasters in the United Kingdom: Learning from tragedy? Organization \& Environment, 7(3), 205-229.

Ellis, R. (1994). Presidential lightening rods: The politics of blame avoidance. Lawrence: University Press of Kansas.

Entman, R. E. (1993). Framing: Toward clarification of a fractured paradigm. Journal of Communication, 43(4), 51-58.

Fischer, J., \& Kaiser, A. (2009). Hiring and firing ministers under informal constraints: Germany. In K. Dowding \& P. Dumont (Eds.), The selection of ministers in Europe: Hiring and firing (pp. 21-41). New York, NY: Routledge.

Florini, A., \& Dehqanzada, Y. (1999). Satellite imagery comes of age. Issues in Science and Technology, 16(1), 45-52.

Graff, V. (2004) 'Meet the Yest Men Who Hoax the World', The Guardian, December 13, 2004, see https://www.theguardian.com/media/2004/dec/13/mondaymediasection5

Green-Pedersen, C. (2002). The politics of justification: Party competition and welfare-state retrenchment in Denmark and the Netherlands from 1982 to 1998. Amsterdam, The Netherlands: Amsterdam University Press.

Hansen, M., Klemmensen, R., Hobolt, S., \& Bäck, H. (2013). Portfolio saliency and ministerial turnover: Dynamics of Scandinavian post war cabinets. Scandinavian Political Studies, 36(3), 227248. 
Hearit, K. M. (2006). Crisis management by apology: Corporate response to allegations of wrongdoing. Mahwah NJ: Lawrence Erlbaum.

Hinterleitner, M. (2017). Reconciling perspectives on blame avoidance behavior. Policy Studies Journal, 15(2), 243-254.

Hinterleitner, M. (2018). Policy failures, blame games and changes to policy practice. Journal of Public Policy, 38(2), 221-242.

Hinterleitner, M., \& Sager, F. (2015). Avoiding blame-a comprehensive framework and the Australian home insulation program fiasco. The Policy Studies Journal, 43(1), 139-161.

Hinterleitner, M., \& Sager, F. (2019). Blame, reputation, and organizational responses to a politicized climate. In T. Bach \& K. Wegrich (Eds.), The blind spots of public bureaucracy and the politics of noncoordination (pp. 133-150). Cham, Switzerland: Palgrave Macmillan.

Hood, C. (2002). The risk game and the blame game. Government and Opposition, 37(1), 15-37.

Hood, C. (2011). The blame game: Spin, bureaucracy, and self-preservation in government. Princeton, NJ: Princeton University Press.

Hood, C., \& Lodge, M. (2006). The politics of public service bargains: Reward, competency, loyaltyand blame. Oxford, U.K.: Oxford University Press.

Hood, C., Jennings, W., \& Copeland, P. (2016). Blame avoidance in comparative perspective: Reactivity, staged retreat and efficacy. Public Administration, 94(2), 542-562.

Hood, C., Jennings, W., Dixon, R., Hogwood, B., \& Beeston, C. (2009). Testing times: Exploring staged responses and the impact of blame management strategies in two examination fiasco cases. European Journal of Political Research, 48(6), 695-722.

Hutter, B.M. (1992) Public accident inquiries: The case of the Railway Inspectorate, Public Administration, 70(3), 177-192.

Indridason, I. H., \& Kam, C. (2008). Cabinet reshuffles and ministerial drift. British Journal of Political Science, 38(4), 621-656.

Inspectorate of Justice and Security (former Inspectie Openbare Orde en Veiligheid, IOOV)(2009) Poldercrash 25 Februari 2009: Een Onderzoek door de Inspectie Openbare Orde en Veiligheid in samenwerking met de Inspectie voor de Gezondheidszorg, The Hague, IOOV. See also: https://www.inspectie-jenv.nl/Publicaties/rapporten/2009/06/22/poldercrash-25-februari-2009

Kasperkevitch, Jana (2016) BP Oil Spill: Judge Grants Final Approval for \$20bn Settlement, The Guardian, April 4, 2016. See also: https://www.theguardian.com/environment/2016/apr/04/bp-oilspill-judge-grants-final-approval-20-billion-dollar-settlement

Konkel, L. (2018, February 7). Cleanup in the Gulf: Oil spill dispersants and health symptoms in deepwater horizon responders. Environmental Health Perspectives, 126(2).

Kuipers, S., Kochanska, K., and Brändström, A. (2011) Chasing Evil, Defending Atrocities: Blame Avoidance and Prisoner Abuse During the War in Iraq, in: L. Svedin (ed.) Ethics and Crisis Management, Charlotte: Information Age Publishing, pp.119-140 
Kuipers, S. L., \& 't Hart, P. (2014). Accounting for crises. In M. Bovens, R. Goodin, \& T. Schillemans (Eds.), The Oxford handbook of political accountability (pp. 589-601). Oxford, U.K.: Oxford University Press.

Kuipers, S. L., \& Welsh, N. H. (2017). Taxonomy of the crisis and disaster literature, themes and types in 34 years of research. Risk, Hazards and Crisis in Public Policy, 8(4), 272-283.

Maestas, C., Atkeson, L., Croom, T., \& Bryant, L. (2008). Shifting the blame, federalism media and public assignment of blame following Hurricane Katrina. Publius: The Journal of Federalism, 38(4), 609-632.

Martijn, M., Tokmetzis, D., Bol, R., \& Postma, F. (2018, July 8). Project Polar: Why we decided to publishing our findings. De Correspondent.

McConnell, A. (2010). Understanding policy success: Rethinking public policy. Basingstroke, U.K.: Palgrave MacMillan.

McConnell, A. (2011). Success? Failure? Something in-between? A framework for evaluating crisis management. Policy and Society, 30(2), 63-76.

McConnell, A., Gauja, A., \& Botterill, L. C. (2008). Policy fiascos, blame management and AWB Limited: The Howard government's escape from the Iraq wheat scandal. Australian Journal of Political Science, 43(4), 599-616.

McGraw, K. M. (1991). Managing blame: An experimental test of the effects of political accounts. American Political Science Review, 85(4), 1133-1157.

Mesquita, B. B, Smith, A., Siverson, R. M., \& Morrow, J. D. (2005). The logic of political survival. Cambridge MA: MIT Press.

Mortensen, P. (2013). Public sector reform and blame avoidance effects. Journal of Public Policy, 33(2), 229-253.

Moynihan, D. P. (2012). Extra-network organizational reputation and blame avoidance in networks: The Hurricane Katrina example. Governance, 25(4), 567-588.

Nohrstedt, D., \& Weible, C. M. (2010). The logic of policy change after crisis: Proximity and subsystem interaction. Risk, Hazards \& Crisis in Public Policy, 1, Article 1.

Pierson, P. (1994). Dismantling the welfare state? Reagan, Thatcher, and the politics of retrenchment. Cambridge, U.K.: Cambridge University Press.

Resodihardjo, S. L., Carroll, B. J., Van Eijk, C. J. A., \& Maris, S. (2016). Why traditional responses to blame games fail: The importance of context, rituals, and sub-blame games in the face of raves gone wrong. Public Administration, 94(2), 350-363.

Resodihardjo, S. L., van Eijk, C. J. A., \& Carroll, B. J. (2012). Mayor vs. police chief: The Hoek van Holland riot. Journal of Contingencies and Crisis Management, 20(4), 231-243.

Romzek, B. S., \& Ingraham, P. W. (2000). Cross pressures of accountability: Initiative, command, and failure in the Ron Brown plane crash. Public Administration Review, 60(3), 240-253.

Rosenthal, U., Charles, M., \& 't Hart, P. (Eds.). (1989). Coping with crisis: The management of disasters, riots and terrorism. Springfield, IL: Charles C. Thomas. 
Schillemans, T., \& Bovens, M. (2011). The challenge of multiple accountability: Does redundancy lead to overload? In M. J. Dubnick \& H. G. Frederickson (Eds.), Accountable governance: Problems and promises (pp. 3-21). Armonk, NY: M. E. Sharpe.

Stark, A. (2011). The tradition of ministerial responsibility and its role in the bureaucratic management of crises. Public Administration, 89(3), 1148-1163.

Stern, E. K. (2017, June). Unpacking and exploring the relationship between crisis management and social media in the era of "smart devices." Homeland Security Affairs, 13, Article 4.

Ström, K. (2003). Parliamentary democracy and delegation. In K. Ström \& T. Bergman (Eds.), Delegation and accountability in parliamentary democracies (pp. 55-106). Oxford, U.K.: Oxford University Press.

Sulitzeanu-Kenan, R. (2006). If they get it right: An experimental test of the effects of the appointment and reports of UK public inquiries. Public Administration, 84(3), (623-653).

Sulitzeanu-Kenan R. (2007). Scything the grass: Agenda-setting consequences of appointing public inquiries in the UK: A longitudinal analysis. Policy \& Politics, 35(4), 629-650.

Sulitzeanu-Kenan, R. (2010). Reflection in the shadow of blame: When do politicians appoint commissions of inquiry? British Journal of Political Science, 40(3), 613-634.

Sulitzeanu-Kenan, R., \& Hood, C. (2005, April 14-20). Blame avoidance with adjectives? Motivation, opportunity, activity and outcome. Presented at ECPR Joint Sessions, Blame Avoidance and Blame Management Workshop, Granada, Spain, April 14-20.

't Hart, P., \& Uhr, J. (2011). How power changes hands: Transition and succession in government. London, U.K.: Palgrave Macmillan.

Thompson, J.D. (1967). Organizations in Action, New York: McGrawHill.

Transportstyrelsens it-affär: (2017, July 17). Detta har hänt. Svt Nyheter.

Turner, B. (1976). The organizational and interorganization development of disasters. Administrative Science Quarterly, 21(3), 378-398.

Ulmer, R. R., \& Sellnow, T. L. (2002). Crisis management and the discourse of renewal: Understanding the potential for positive outcomes of crisis. Public Relations Review, 28, 361-365.

Vis, B. (2016). Taking stock of the comparative literature on the role of blame avoidance strategies in social policy reform. Journal of Comparative Policy Analysis: Research and Practice, 18(2), 122-137.

Walsh, J. I. (2006). Policy failure and policy change: British security policy after the Cold War. Comparative Political Studies, 39(4), 490-518.

Weaver, K. (1986). The politics of blame avoidance. Journal of Public Policy, 6(4), 371-398.

Weaver, R. K. (2018). The nays have it: How rampant blame generating distorts American policy and politics. Political Science Quarterly, 133(2), 259-289.

Woodhouse, D. (2004). UK ministerial responsibility in 2002: The tale of two resignations." Public Administration, 82(1), 1-19.

Wukich, C. (2019). Preparing for disaster: Social media use for household, organizational, and community preparedness. Risk, Hazards and Crisis in Public Policy, 10(2), 233-260 
